\title{
Growth Performance and Nutritional Quality of Nile tilapia Caged in Northern Benin Water Reservoirs Exposed to Agricultural Effluents
}

\author{
Rodrigue Orobiyi Edéya Pèlèbè ${ }^{1,2, * \mathbb{D}}$, Ibrahim Imorou Toko1, Issa Nahoua \\ Ouattara², Eloi Yatchégnon Attakpa ${ }^{3}$, Jean Fall, Elie Montchowui ${ }^{5}$, Célestin \\ Melecony Ble 6
}

\begin{abstract}
${ }^{1}$ Research Laboratory in Aquaculture and Aquatic Ecotoxicology, Faculty of Agronomy, University of Parakou, Benin. ${ }^{2}$ Laboratory of Hydrobiology and Water Ecotechnology, Biosciences Training and Research Unit, University Félix HOUPHOUET-BOIGNY, Côte d'Ivoire.

${ }^{3}$ Laboratory of Animal Ecology, Health and Production, Faculty of Agronomy, University of Parakou, Benin.

${ }^{4}$ University Institute of Fisheries and Aquaculture, University Cheikh Anta Diop, Senegal.

${ }^{5}$ School of Aquaculture, National University of Agriculture, Benin.

${ }^{6}$ Aquaculture Department, Oceanology Research Center, Côte d'Ivoire.
\end{abstract}

\section{Article History}

Received Apr 30, 2020

Accepted Jun 5,2020

First Online Jun 5,2020

\section{Corresponding Author}

Tel.: +22994824211/96975762

E-mail: peleberodrigue@yahoo.fr

\section{Keywords}

Oreochromis niloticus

Agricultural pesticides

Rearing performance

Water reservoirs

Benin

\begin{abstract}
Water reservoirs, widespread in northern Benin providing fish for consumption to the near-by population, are exposed to agricultural pesticides from cotton production. To highlight their aquaculture potential, a 120-days experiment was conducted on growth performance and nutritional quality of Oreochromis niloticus (7.00 $\pm 0.06 \mathrm{~g})$. A $2 \times 2$ factorial design with water reservoirs (Batran and Songhaï chosen as site polluted by pesticides and a reference environment, respectively) and cage culture systems (Cage bottom on Seaground, CBOS and cage bottom above Seaground, CBAS) was used. Transparency and dissolved oxygen's means values were significantly higher in Songhaï $(P<0.05)$ compared to Batran. Final survival rates are quite high and satisfactory (75$99 \%)$. Only the water reservoir had a significant influence on fish growth. Fish reared in CBOS at Songhaï significantly displayed the highest values of final mean body weight $(70.63 \pm 9.90 \mathrm{~g})$, daily weight gain $\left(0.53 \pm 0.08 \mathrm{~g} \mathrm{day}^{-1}\right)$ and specific growth rate $(1.92 \pm$ $0.11 \%$ day $\left.^{-1}\right)$, while the lowest values were found with the same culture system at Batran (45.62 $\pm 1.22 \mathrm{~g}, 0.32 \pm 0.01 \mathrm{~g} \mathrm{day}^{-1}, 1.56 \pm 0.02 \%$ day $^{-1}$, respectively). Water reservoir location had a significant effect on lipid productive value, total ash and gross energy retention.
\end{abstract}

\section{Introduction}

Local fish production in Benin is recorded to have failed to meet the country's domestic demand (Rurangwa, van den Berg, Lalèyè, van Duijn, \& Rothuis, 2014; Kpenavoun, Gandonou, Adegbidi, \& Abokini, 2017). The country annually imports a huge quantity of frozen fish, which results in depreciation of the currency (INSAE, 2016). The sanitary quality of these imported fish with regard to the current conditions of storage, transportation and commercialization remains questionable (Wabi, Gbaguidi, Anihouvi, Azokpota, \& Kpodékon, 2012). Therefore, fish farming has been identified as a suitable alternative for increasing the national fish production level and ensuring the sanitary and nutritional safety for the population (MAEP, 2017). To execute this vision, the government's policy aims at valorizing each region's aquaculture potentialities such as the numerous northern Benin water reservoirs (Azonsi et al., 2008), which provide the big part of fresh fish to the local population (Pèlèbè et al., not published). In addition, northern part of Benin is the highest 
agricultural production zone in Benin, especially in terms of cotton production (Ton, 2004; Agbohessi, 2014). At the current state of its technical practice, pests' control of cotton plant requires the application of a large quantity of a various chemical pesticide (Matthess, van den Akker, Chougourou, \& Midingoyi, 2005; Houndekon, 2014). Water reservoirs are thus exposed to agricultural pesticides (Agbohessi et al., 2015; Pèlèbè, Imorou Toko, Ouattara, Attakpa, \& Montchowui, 2019), which have become pollutants, generating major concerns in this important agricultural zone (Agbohessi, Imorou Toko, \& Kestemont, 2012; Adéchian et al., 2015; Lawani, Kelome, Agassounon Djikpo Tchibozo, Hounkpe, \& Adjagodo, 2017; Zoumenou, 2019). Several families of pesticide molecules are found in these reservoirs. Besides the pyrethroids, neonicotinoids and organophosphorus compounds that are currently authorized in agriculture in Benin, organochlorine pesticides banned since 2009 in Benin are recently detected and quantified in northern Benin water reservoirs (Pèlèbè et al., 2019). In the aquatic ecosystems, certain pesticides molecules remain in the water column, whereas others accumulate in the sediments (Vigano, Arillo, Falugi, Melodia, \& Polesello, 2001; Zoumenou, 2019). Consequently, the exposure of fish to these pollutants and its associatedeffects are variable according to organism preference for living zone (Agbohessi et al., 2015). Considering the reality that fish production in water reservoirs is a major priority for Benin and its communal authorities, the question however posed is of which does fish farming system optimizes fish production while minimizing the effect of agricultural pesticides polluting the Benin cotton basin water reservoirs on zootechnical and nutritional performance of $O$. niloticus (Linnaeus, 1758), an important fish in the population's diet? The answer to this question carries a great scientific interest and will have interesting implications on the development of
Benin fish culture sector. Therefore, the purpose of the present study was to compare the rearing performance of Nile tilapia in cage bottom layer suspended above seaground without contact to sediment, which enable fish to remain only in the water column, and cage bottom layer set on the seaground with contact to sediment in which fish were able to gain access to both water column and sediments. Experiments were made simultaneously in a polluted water reservoir and a reference water reservoir.

\section{Materials and Methods}

\section{Experimental Water Reservoirs}

Experiments were conducted in two water reservoirs with different levels of pollution. The first one is the Batran water reservoir in Mekrou river basin chosen as a polluted environment (Agbohessi et al., 2015; Imorou Toko et al., 2018; Zoumenou, 2019) and located at Banikoara, the main pesticides consumer municipality in Benin (Agbohessi, Imorou Toko, Yabi, Dassoundo-Assogba, \& Kestemont, 2011; Gouda, 2018). This water reservoir has dike and concrete weir. The activities around are market gardening, cereal sand cotton production. It is also used for domestic purposes and for livestock watering. The second one is the Songhaï water reservoir located outside of cottonproducing basin, at N'Dali in the Okpara river Basin. It was assigned to be the reference ecosystem (Imorou Toko et al., 2018; Zoumenou, 2019). It has a small weir and a compacted earth dike. The activities around this water reservoir are fish farming and market gardening. Songhaï water reservoir is very distant (about $300 \mathrm{~km}$ ) from Batran water reservoir and does not receive any tributary from the Beninese cotton basin composed of Kandi, Gogounou, Banikoara, Kérou et Segbana municipalities (Ton, 2004). These two water reservoirs
Cage bottom above Seaground (CBAS)

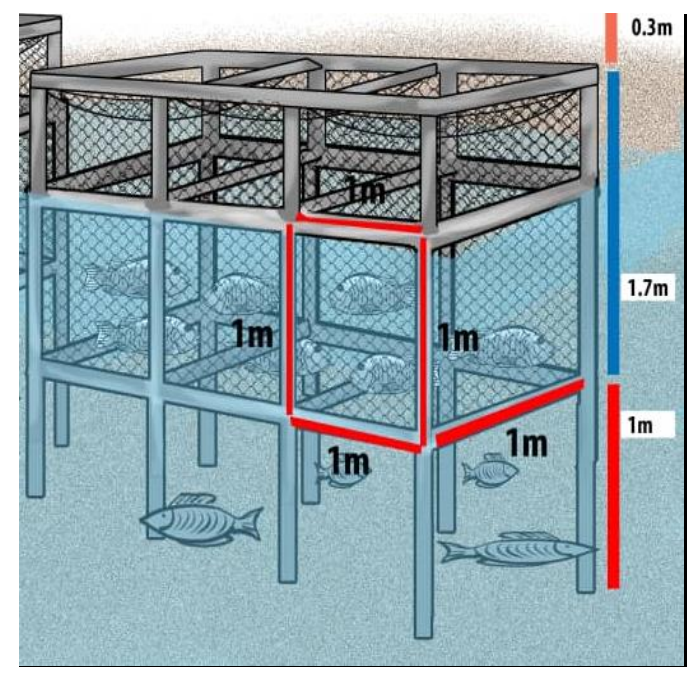

Cage bottom on Seaground (CBOS)

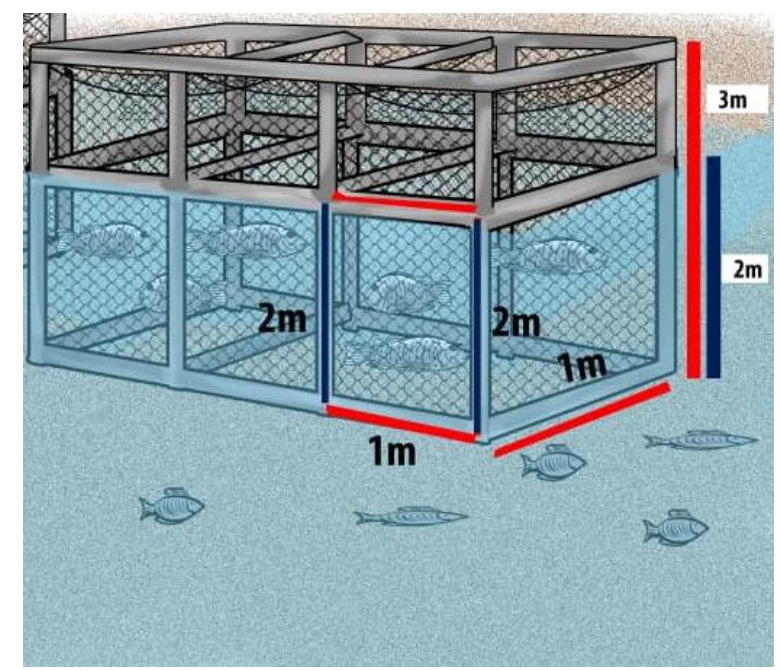

Figure 1. Schematic of the experimental device in each water reservoir. 
do not dry up during the dry season but have similar climatic conditions (Adam \& Boko, 1993).

\section{Culture Systems Description and Experimental Design}

Cage bottom layer suspended above seaground without contact to sediment (Cage bottom above Seaground, CBAS) and cage bottom layer set on the seaground with contact to sediment (Cage bottom on Seaground, CBOS) were used as culture systems. Unlike floating cages, which require the construction of a floating collar that can cover more than half of the total costs incurred (Aïzonou, Achoh, \& Agadjihouèdé, 2019), these fixed cages are made of net simply attached to frame embedded in the sediment and appeared relatively less expensive (Beveridge, 1985). The experiment had $2 \times 2$ factorial design. The first factor was related to water reservoirs (Batran and Songhaï) and the second factor was culture system (Cage bottom above Seaground, CBAS and Cage bottom on Seaground, CBOS). A train of three (3) CBAS (long $x$ width $x$ height: 1 $x 1 \times 1.70 \mathrm{~m}$ ) and another one of three (3) CBOS (long $x$ width $\mathrm{x}$ height: $1 \times 1 \times 3 \mathrm{~m}$ ) were installed in each water reservoir (Figure 1). The gap between the base of CBAS and the aquatic bottom was $1 \mathrm{~m}$, whereas the base of CBOS was tightly in the sediment with stakes. At the onset of the experiments, culture units were installed in the water reservoirs to have $1 \mathrm{~m}^{3}$ water depth; however, during the test, the water level in the reservoirs varied due to the addition of rainwater. To prevent fish loss through jumping or bird predation as well as from thieves and flood, all the culture units were equipped with covers net.

\section{Experimental fish}

In each water reservoir, mixed sex 0 . niloticus juveniles (average mean weight $=7.00 \pm 0.05 \mathrm{~g}$ ) were obtained from "Beniel Fish" fish culture farm located at Abomey-Calavi and were transported in aerated plastic bags to the experimental stations. They were adapted to the experimental conditions for two weeks and were hand-fed with a commercial tilapia pellets floating feed "Le Gouessant" twice a day until $24 \mathrm{~h}$ before the beginning of the experiment.

\section{Experimental Procedures and Water Quality Monitoring}

The study was carried out simultaneously during 120 days (May - October) in the two water reservoirs, and the maintenance of installed culture units was made each month. At the start of the experiment, fish were randomly stocked at 100 juveniles per replicate of both culture systems based on the works of Legendre (1986), Ouattara (2004) and Nobah (2007). Fish feed was purchased from "Petit Poisson SARL", Abomey-Calavi and stored in a cool and dry place during the experiments. Fish were hand-fed twice a day (between 8-9:00 am and 5-6:00 pm) and six days in a week, to apparent satiation with "Le Gouessant" (type 1: $3.2 \mathrm{~mm}$ of diameter, $30 \%$ of crude protein and $9 \%$ of crude lipid; type 2: $4 \mathrm{~mm}$ of diameter, $32 \%$ of crude protein and $9 \%$ of crude lipid). However, the quantity of daily distributed feed was calculated according to Mélard (1986) taking into account the biomass determined at the last fish growth control which was performed each 30 days. At each feeding, care was taken to stop feeding as soon as the fish stopped eating and quantity of the distributed feed was recorded. For fish growth control, 30 fish in each replicated culture unit were sampled early in the morning (7-9:00 am) using a scoop net and batch weighted with an electronic balance (PHILIPS, 5 $\mathrm{kg}, 0.1 \mathrm{~g})$. Dead fish were removed and recorded during the experiment. At the end of the experiment, all fish were harvested and the total number of fish in each replicated culture unit was counted and weighed. 30 fish per culture system (10 from each replicate) were randomly collected for individual weight and total length measurement. All fish were anesthetized with tricaine methane-sulfonate, MS-222 (Sigma-Aldrich) before measurement. At three days intervals, water temperature and dissolved oxygen, $\mathrm{pH}$ and water transparency were measured in each replicate of infrastructure using an oxy-thermometer HANNA (HI 9146), a pH-meter WTW 3210 and a Secchi disk graduated in centimeter, respectively. These different measurements were made before feeding the fish.

\section{Sampling and Biochemical Analyses}

Prior to the commencement of the experiment, 24 fish were randomly collected and pooled in three integrated samples. At the end of the rearing trial, three fish were randomly selected from each infrastructure replicate and pooled to provide one sample. These samples were stored at $-80^{\circ} \mathrm{C}$ (Schreck et Moyle, 1990) for biochemical analyses on the whole scaled and gutted fish at the Nutrition Laboratory of "Centre de Recherches Océanologiques" of Abidjan, Côte d'Ivoire. Dry matter, total ash, crude protein and total lipid were analyzed according to standard methods (AOAC, 2003). Moisture content was estimated by drying the samples at $105^{\circ} \mathrm{C}$ during $24 \mathrm{~h}$ in a drying oven. The crude protein content $(\mathrm{N} \times 6.25)$ was estimated using the Kjeldahl method. Total lipid content was determined after petroleum ether extraction using Soxhlet system. Ash content was determined by combusting samples in a muffle furnace at $550^{\circ} \mathrm{C}$ for $12 \mathrm{~h}$. Three trials were carried out for each analyzed compound. Carbohydrate was estimated by subtracting crude protein, total lipid, moisture and ash values from 100 (Jobling, 1983). Note that we have to take into account the loss of moisture to find in the wet matter (fresh fish), the content of an element " $A$ " measured in the dry matter by applying the 
following formula: $A$ ( $\%$ fresh material) $=A(\%$ dry matter) x (dry matter content / 100).

\section{Zootechnical Performance}

Survival and growth parameters (survival rate: SR, final mean body weight: $W_{f}$, variation coefficients of initial and final means body weights: $\mathrm{CV}_{i}$ and $C V_{f}$, daily weight gain: DWG, specific growth rate: $S G R$ and condition factor: $\mathrm{K}$ ), feed utilization parameters (feed efficiency: FE, protein efficiency ratio: PER, protein productive value: PPV, lipid productive value: LPV) were calculated as follows:

SR $(\%)=100 \times($ final fish number $) /($ initial fish number $)$

$W_{f}(g)=B_{f} N^{-1}$ where $B_{f}=$ final fish biomass $(g)$ and $N=$ number of survivors

$$
\begin{gathered}
\mathrm{CV}_{\mathrm{i}}(\%) \text { and } \mathrm{CV}_{\mathrm{f}}(\%)=100\left(\mathrm{SD} \text { mean }^{-1}\right) \text { where } \mathrm{SD}= \\
\text { standard deviation }
\end{gathered}
$$

DWG $\left(\mathrm{g} \mathrm{day}^{-1}\right)=\left(\mathrm{W}_{\mathrm{f}}-\mathrm{W}_{\mathrm{i}}\right) \mathrm{t}^{-1}$ where $\mathrm{W}_{\mathrm{i}}=$ initial mean body weight $(\mathrm{g})$ and $\mathrm{t}=$ duration of experiment (days)

$$
\begin{gathered}
\operatorname{SGR}\left(\% \text { day }^{-1}\right)=100 \times\left[\ln \left(\mathrm{W}_{\mathrm{f}}\right)-\ln \left(\mathrm{W}_{\mathrm{i}}\right)\right] \mathrm{t}^{-1} \\
\mathrm{~K}(\%)=100 \mathrm{~W}_{\mathrm{f}} \mathrm{LT}^{-3} \text { where } \mathrm{W}_{\mathrm{f}} \text { is in } \mathrm{g} \text { and } \mathrm{LT}=\text { fish total } \\
\text { length }(\mathrm{cm})
\end{gathered}
$$

$F E=\left(B_{f}-B_{i}\right)(\text { weight of total feed used })^{-1}$

PER $=\left(B_{f}-B_{i}\right)$ (weight of total used proteins $)^{-1}$

$P P V=\left[\left(\right.\right.$ crude protein of final fish $\left.\times B_{f}\right)$ - (crude protein of initial fish $\times B_{i}$ )]/ (crude protein of feed $\times$ weight of total used feed)

$L P V=\left[\left(\right.\right.$ total lipid of final fish $\left.\times B_{f}\right)$-(total lipid of initial fish $\times B_{i}$ )]/ (total lipid of feed $\times$ weight of total used feed)

\section{Gross Energy Content and Retention}

Gross energy content was calculated by making assumptions of the appropriate caloric conversion terms for each fish body component. Calculations were based on Jobling $(1983 ; 1994)$ and the following values were used: $23.7 \mathrm{~kJ} . \mathrm{g}^{-1}$ for protein, $39.5 \mathrm{kJ.g}^{-1}$ for lipid and 17.2

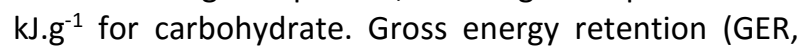
$\mathrm{kJ} / \mathrm{g}$ ) was computed according to following formula: GER $(\%)=100 \times\left[\left(\right.\right.$ Gross energy of final fish $\left.\times \mathrm{B}_{f}\right)-($ Gross energy of initial fish $\times B_{i}$ )]/ (Gross energy of feed $\times$ weight of total used feed)]. Feed gross energy (18.5 kJ.g $\left.{ }^{1}\right)$ was provided by the manufacturer of the used feed namely SICA DU GOUESSANT company (France).

\section{Statistical Analysis}

Results were expressed as mean \pm standard deviation. To test difference of physical and chemical, zootechnical and nutritional data between water reservoirs and culture systems' modalities, two-way analysis of variance (ANOVA II) was used. Multiple comparisons of both main factor effects and their interaction were done using Tukey Honest Significant Difference test. Differences were regarded as significant when $\mathrm{P}<0.05$. All statistical analyses were performed using STATISTICA 6.1 software (Statsoft, Inc.).

\section{Results}

\section{Physical and Chemical Parameters in Tested Infrastructures at the Water Reservoirs}

Water quality parameters of both water reservoirs were presented in table 1 . Measured values were comparable between the two water reservoirs except for dissolved oxygen and disk Secchi transparency, which were significantly higher in Songhaï water reservoir $(P<0.05)$. There was no significant difference between culture systems for water quality in each water reservoir.

\section{Zootechnical performance}

Overall, survival rates were between $75 \%$ and $99 \%$ (Figure 2) and was significantly influenced by the factor "water reservoir". Recorded values were higher in Songhaï compared to Batran. The increase in mean body weight during experimental period is shown graphically

\begin{tabular}{|c|c|c|c|c|}
\hline \multirow[t]{2}{*}{ Parameters } & \multicolumn{2}{|c|}{$\begin{array}{c}\text { Batran water reservoir } \\
\left.\text { (Agriculture polluted reservoir }{ }^{A}\right)\end{array}$} & \multicolumn{2}{|c|}{$\begin{array}{l}\text { Songhaï water reservoir } \\
\text { (Reference ecosystem }{ }^{\mathrm{B}} \text { ) }\end{array}$} \\
\hline & CBOS & CBAS & CBOS & CBAS \\
\hline $\mathrm{T}\left({ }^{\circ} \mathrm{C}\right)$ & $28.37 \pm 2.28^{a}$ & $28.66 \pm 2.27^{a}$ & $28.69 \pm 1.58^{a}$ & $28.77 \pm 1.56^{a}$ \\
\hline $\mathrm{O}_{2}(\mathrm{mg} / \mathrm{l})$ & $3.11 \pm 1.43^{a}$ & $3.16 \pm 1.35^{a}$ & $4.96 \pm 1.19^{b}$ & $4.82 \pm 1.10^{b}$ \\
\hline $\mathrm{pH}$ & $6.82 \pm 0.58^{a}$ & $6.92 \pm 0.52^{a}$ & $6.84 \pm 0.28^{a}$ & $6.70 \pm 0.41^{a}$ \\
\hline Transparency $(\mathrm{cm})$ & $19.03 \pm 16.73^{a}$ & $18.52 \pm 16.51^{a}$ & $31.22 \pm 4.57^{b}$ & $33.62 \pm 4.62^{b}$ \\
\hline
\end{tabular}
in figure 3.

Table 2 shows the mean values of growth and feed utilization parameters at the end of the experiments.

Table 1. Water quality parameters during experiments

Water reservoir had significant effect on some parameters; in each table line, values sharing a same superscript letter are not significantly different (P> 0.05), ${ }^{A}$ Agbohessi et al., 2015; Imorou Toko et al., 2018; Zoumenou, 2019; ${ }^{B}$ Imorou Toko et al., 2018; Zoumenou, 2019. CBOS: Cage bottom on Seaground, CBAS: Cage bottom above Seaground. 


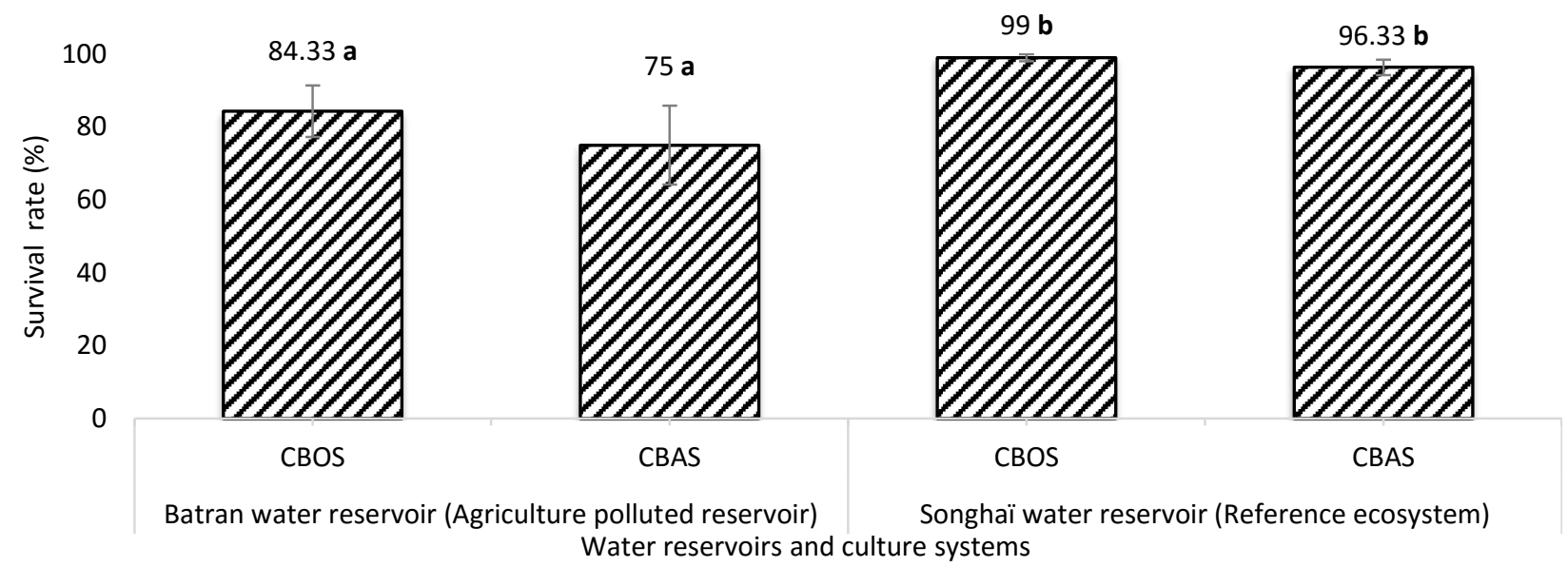

Figure 2. Survival rates of $O$. niloticus reared for 120 days in northern Benin water reservoirs. Water reservoir had significant effect; means sharing a same letter are not significantly different $(\mathrm{P}>0.05) ;(\mathrm{n}=3)$. CBOS: Cage bottom on Seaground, CBAS: Cage bottom above Seaground.

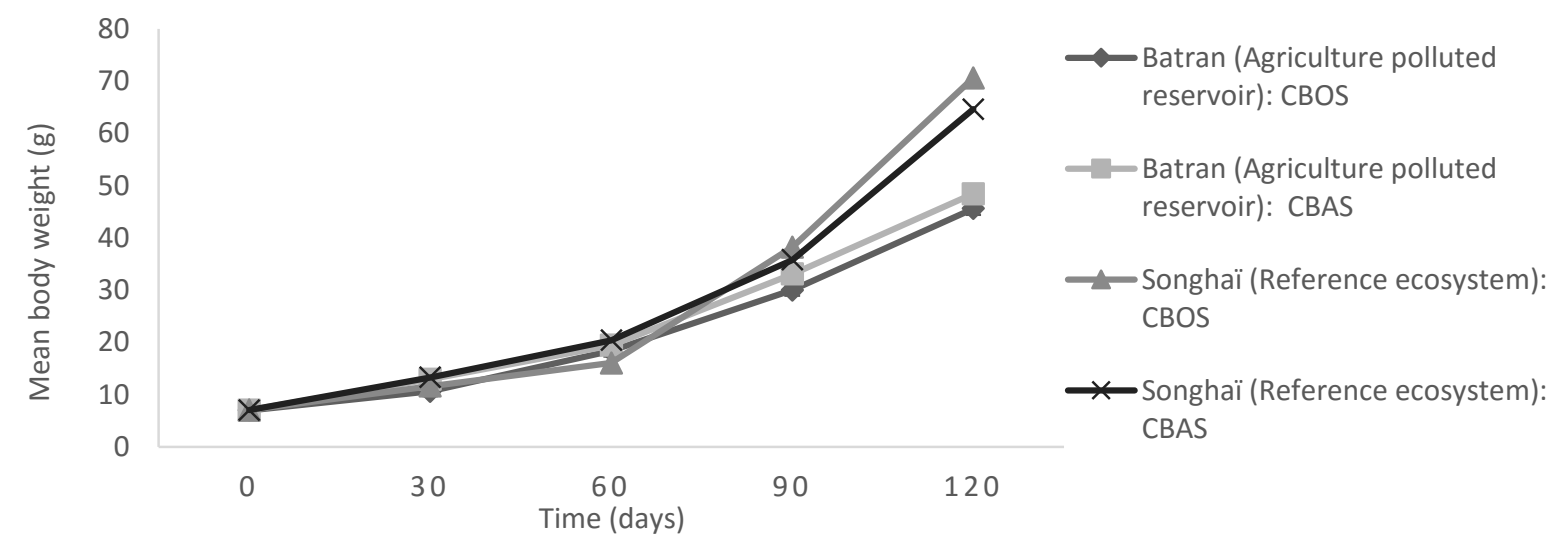

Figure 3. Increase in mean body weight of $O$. niloticus during 120 days-rearing experiments in northern Benin water reservoirs. CBOS: Cage bottom on Seaground, CBAS: Cage bottom above Seaground.

Weights of initial fish were very homogeneous ( $P>0.05)$, whereas the heterogeneity of the final weight was relatively high in fish reared in CBAS regardless of the water reservoir (Table 2). Only water reservoir had a significant effect on growth parameters namely $W_{f}$, DWG and SGR $(P<0.05)$ (Table 2). They were significantly higher in Songhaï as compared to Batran. The condition index did not vary significantly between culture systems for the two water reservoirs (Table 2). Concerning feed utilization parameters, only LPV varied significantly between the two water reservoirs (Table 2).

\section{Proximate Body Biochemical Composition}

Table 3 presents the cultured fish body biochemical composition. Water reservoir had significant effect on total ash. There were a significant difference between Songhaï and Batran for both culture systems $(P<0.05)$.

\section{Energy Content and Energy Retention}

Table 4 displays the average gross energy content of the fish and the contribution of lipid, protein and carbohydrate to its formation. Water reservoir had no significant effect on the gross energy content in fish (Table 4). Regardless of the water reservoir and the culture system, protein have the greatest contribution to the total value of the gross energy compared to the two other nutrients. Between the two water reservoirs, the contribution percentages of lipid to the gross energy formation are comparable. However, these contribution percentages are higher for protein and carbohydrate at Songhaï and Batran, respectively (Table 4).

Water reservoir had a significant effect on the gross energy retention in fish without there being no difference between the culture systems in the same reservoir. The fish reared in the Batran water reservoir were exhibited the highest energy retention values (Figure 4).

\section{Discussion}

The cotton basin of northern Benin is essentially an agricultural area and pesticides are the major pollutants that contaminate the water reservoirs. In the present study, we evaluated for first time, the biotechnical parameters in $O$. niloticus reared in two different culture 
Table 2. Growth and feed utilization parameters of $O$. niloticus reared for 120 days in northern Benin water reservoirs $(n=3)$

\begin{tabular}{|c|c|c|c|c|}
\hline \multirow[t]{2}{*}{ Parameters } & \multicolumn{2}{|c|}{$\begin{array}{c}\text { Batran water reservoir } \\
\left(\text { Agriculture polluted reservoir }{ }^{A}\right)\end{array}$} & \multicolumn{2}{|c|}{$\begin{array}{l}\text { Songhaï water reservoir } \\
\text { (Reference ecosystem }^{\text {B) }}\end{array}$} \\
\hline & CBOS & CBAS & CBOS & CBAS \\
\hline$W_{i}(g)$ & $6.98 \pm 0.05^{a}$ & $7.02 \pm 0.07 a$ & $7 \pm 0.09 a$ & $7 \pm 0.00^{a}$ \\
\hline $\mathrm{CV}_{\mathrm{i}}(\%)$ & 0.71 & 1 & 1.31 & 0.04 \\
\hline$W_{f}(g)$ & $45.62 \pm 1.22^{a}$ & $48.42 \pm 13.31^{a}$ & $70.63 \pm 9.90^{b}$ & $64.65 \pm 15.31^{b}$ \\
\hline $\mathrm{CV}_{\mathrm{f}}(\%)$ & 2.67 & 27.49 & 14.02 & 23.68 \\
\hline DWG (g day $\left.{ }^{-1}\right)$ & $0.32 \pm 0.01^{a}$ & $0.35 \pm 0.11^{a}$ & $0.53 \pm 0.08^{b}$ & $0.48 \pm 0.13^{b}$ \\
\hline SGR (\% day $\left.{ }^{-1}\right)$ & $1.56 \pm 0.02^{a}$ & $1.58 \pm 0.23^{a}$ & $1.92 \pm 0.11^{b}$ & $1.84 \pm 0.21^{b}$ \\
\hline $\mathrm{K}(\%)$ & $1.78 \pm 0.05^{a}$ & $1.77 \pm 0.05^{a}$ & $1.69 \pm 0.05^{a}$ & $1.72 \pm 0.13^{a}$ \\
\hline $\mathrm{FE}$ & $2.06 \pm 0.08^{a}$ & $2.21 \pm 0.48^{a}$ & $1.63 \pm 0.25^{\mathrm{a}}$ & $1.61 \pm 0.59^{a}$ \\
\hline PER & $6.65 \pm 0.26^{a}$ & $7.14 \pm 1.56^{a}$ & $5.25 \pm 0.80^{a}$ & $5.21 \pm 1.9^{a}$ \\
\hline PPV & $0.73 \pm 0.37^{a}$ & $0.72 \pm 0.44^{a}$ & $0.75 \pm 0.17^{a}$ & $0.70 \pm 0.27^{a}$ \\
\hline LPV & $1.10 \pm 0.18^{a}$ & $1.21 \pm 0.20^{a}$ & $0.81 \pm 0.14^{b}$ & $0.72 \pm 0.27^{b}$ \\
\hline
\end{tabular}

Water reservoir had significant effect on some parameters; in each table line, values sharing a same superscript letter are not significantly different (P>0.05). ${ }^{A}$ Agbohessi et al., 2015; Imorou Toko et al., 2018; Zoumenou, 2019. ${ }^{B}$ Imorou Toko et al., 2018; Zoumenou, 2019. CBOS: Cage bottom on Seaground, CBAS: Cage bottom above Seaground.

Table 3. Proximate biochemical composition (\% of fresh whole scaled and gutted fish matter basis) of $O$. niloticus reared for 120 days in northern Benin water reservoirs $(n=3)$

\begin{tabular}{|c|c|c|c|c|}
\hline \multirow[t]{2}{*}{ Parameters } & \multicolumn{2}{|c|}{$\begin{array}{c}\text { Batran water reservoir } \\
\text { (Agriculture polluted reservoir }{ }^{\mathrm{A}} \text { ) }\end{array}$} & \multicolumn{2}{|c|}{$\begin{array}{l}\text { Songhaï water reservoir } \\
\text { (Reference ecosystem }^{\text {B) }}\end{array}$} \\
\hline & $\mathrm{CBOS}$ & CBAS & $\mathrm{CBOS}$ & CBAS \\
\hline Moisture & $76.09 \pm 0.27^{a}$ & $76.36 \pm 0.68^{a}$ & $76.46 \pm 0.19^{a}$ & $76.66 \pm 1.08^{a}$ \\
\hline Total ash & $3.13 \pm 0.07^{\mathrm{ad}}$ & $2.96 \pm 0.20^{c d}$ & $3.77 \pm 0.26^{b c}$ & $3.90 \pm 0.03^{a b}$ \\
\hline Total lipid & $4.41 \pm 0.47^{\mathrm{a}}$ & $4.49 \pm 0.11^{a}$ & $4.31 \pm 0.18^{a}$ & $3.87 \pm 0.37^{\mathrm{a}}$ \\
\hline Crude protein & $10.03 \pm 4.80^{a}$ & $9.49 \pm 5.22^{a}$ & $13.39 \pm 1.09 a$ & $12.51 \pm 0.57^{a}$ \\
\hline Carbohydrate & $6.34 \pm 4.89^{a}$ & $6.70 \pm 4.81^{a}$ & $2.07 \pm 1.09^{a}$ & $3.05 \pm 0.79^{a}$ \\
\hline
\end{tabular}

Table 4. Gross energy content (\% of fresh whole scaled and gutted fish matter basis) of $O$. niloticus reared for 120 days in northern Benin water reservoirs $(n=3)$

\begin{tabular}{lcccc}
\hline Parameters & \multicolumn{2}{c}{$\begin{array}{c}\text { Batran water reservoir } \\
\text { (Agriculture polluted reservoir }\end{array}$} \\
\cline { 2 - 5 } & CBOS & CBAS & \multicolumn{2}{c}{$\begin{array}{c}\text { Songhaï water reservoir } \\
\text { (Reference ecosystem }^{\mathrm{B}} \text { ) }\end{array}$} \\
\hline Gross energy content & $5.21 \pm 0.26^{\text {a }}$ & $5.17 \pm 0.41^{\text {a }}$ & $5.23 \pm 0.09^{\text {a }}$ & $5.02 \pm 0.24$ a $^{\text {CBOS }}$ \\
Lipid\% & 33.45 & 34.24 & 32.54 & 30.46 \\
Protein\% & 45.61 & 43.49 & 60.65 & 59.08 \\
Carbohydrate\% & 20.94 & 22.27 & 6.81 & 10.46 \\
\hline
\end{tabular}

Water reservoir had no significant effect on the gross energy content; in the first line of the table, values sharing a same superscript letter are not significantly different (P>0.05). ${ }^{A}$ Agbohessi et al., 2015; Imorou Toko et al., 2018; Zoumenou, 2019.

systems (Cage bottom on Seaground, CBOS and Cage bottom above Seaground, CBAS) installed in water reservoirs located in and outside of the cotton basin (Batran and Songhaï, respectively). Measured values of temperature, dissolved oxygen and $\mathrm{pH}$ during experiments in both water reservoirs were within the accepted range by 0 . niloticus, $21-30^{\circ} \mathrm{C},>2.3 \mathrm{mg} / \mathrm{l}$ and 6-9, respectively (Balarin \& Hatton, 1979; Mélard, 1986; Kestemont, Micha, \& Falter, 1989; Ross, 2000). However, water transparency seemed to be low in Batran (Colman et al., 1992). But, this could not be a problem to the technical feasibility of Nile tilapia culture in the northern Benin water reservoirs because of its adaptive ability to a wide range of environmental conditions (El-Saidy \& Gaber, 2005). The high survival rates $(75-99 \%)$ of fish confirmed this hypothesis. In fact, values measured for this parameter can be considered as good because they were not less than $75 \%$ of the initial number of fish as Morissens, Roche, and Aglinglo (1986) recommended. The significant effect of water reservoir observed on fish survival may be due to poor water transparency in Batran. Nevertheless, our results are better than those of Legendre, Hem, and Cissé (1989) and Ouattara, Teugels, N'Douba, and Philippart (2003), $77.40 \%$ and $83 \%$ for a cichlid fish, Sarotherodon melanotheron reared in cage-enclosures in Ebrié lagoon and floating cages in Lake Ayamé, respectively. Gibran et al. (2008) also reported a high survival rate (95\%) for 


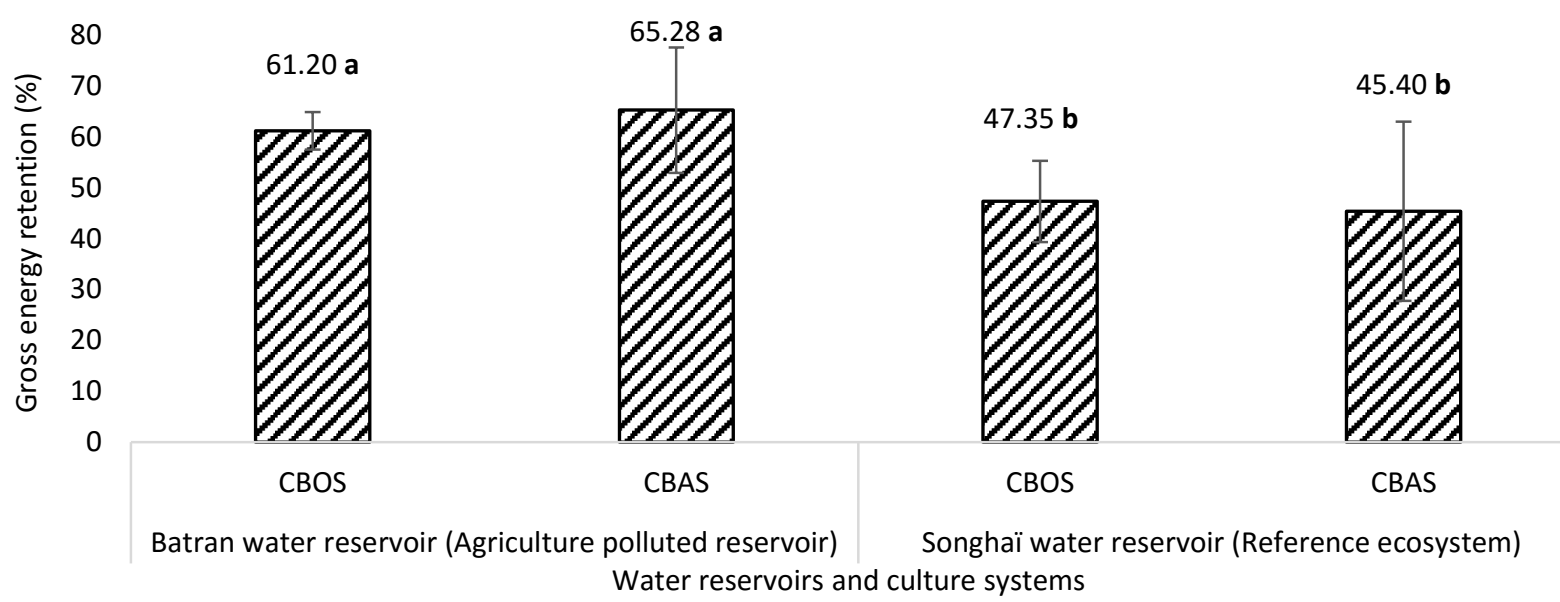

Figure 4. Gross energy retention (B) in O. niloticus reared for 120 days in northern Benin water reservoirs. Water reservoir had significant effect; means sharing a same letter are not significantly different ( $P>0.05) ;(n=3)$. CBOS: Cage bottom on Seaground, CBAS: Cage bottom above Seaground.

mixed sex 0 . niloticus during a 150-day rearing in cages in Kuriftu Lake.

Variation coefficients of the final mean body weight are relatively high in fish reared in CBAS, which may be due to a non-identic accessibility of reared fish to the given feed (Garcia et al., 2013).

The significant effect of the factor "water reservoir" on the measured growth parameters in 0 . niloticus could be related to the difference in the level of contamination by pesticides since Batran water reservoir, in which growth parameters are low, is more contaminated with very dangerous pesticide residues than Songhaï water reservoir (Imorou Toko et al., 2018; Zoumenou, 2019 ; Zoumenou et al., 2019). But the fact that the majority of feed efficiency values are similar in all treatments also suggests that fish growth was in accordance with amount of feed that they consume. The statistical similarity existing between fish reared in CBAS and $\mathrm{CBOS}$ regardless of the water reservoir for growth parameters could be explained by the fact that $O$. niloticus is a pelagic fish and prefers living and eating at water column. Therefore, this species living conditions can be considered as similar in the two fish culture systems infrastructures. However, the water circulation below the suspended cage (CBAS) constitute an advantage compared to the cage with bottom situated directly on seaground (CBOS). It may help to avoid material (fecal material, uneaten diet, etc.) accumulation on the bottom that could lower the dissolved oxygen level in the cage environment.

Despite the variability in the experimental conditions (initial mean body weight, species, rearing conditions and quality of the food used), we compared growth pattern of Nile tilapia in the present work with other studies.

Regardless of the water reservoir and infrastructure, the obtained final mean body weights were lower than the value $104.7 \mathrm{~g}$ obtained by Ouattara et al. (2003) during 336 day-rearing in cages of monosex males of S. melanotheron. DWG at Songhaï are superior to $0.36 \mathrm{~g} \mathrm{day}^{-1}$ and $0.29 \mathrm{~g} \mathrm{day}^{-1}$ respectively reported by Legendre et al. (1989) for mixed sex rearing of $S$. melanotheron in cage-enclosures installed in Ebrié lagoon and Ouattara et al. (2003) for monosex males rearing of the same species. They are also greater than $0.30 \mathrm{~g} \mathrm{day}^{-1}$ obtained in Tilapia guineensis reared in cage-enclosures in Ebrié lagoon (Legendre, 1986). DWG obtained with CBAS was lower compared to $1.01 \mathrm{~g} \mathrm{day}^{-1}$ exhibited by mixed sex juveniles of Nile tilapia during their rearing at 100 individuals. $\mathrm{m}^{-3}$ in cages installed in Lac kuriftu, Ethiopia (Gibtan, Getahun, \& Mengistou, 2008). Contrary, DWG obtained with CBOS at Batran was feeble while those obtained at Songhaï with the same culture system was high compared to 0.46 gday $^{-1}$ reported by Chakraborty, Mazumdar, Chatterji, and Banerjee (2011) with males of $O$. niloticus reared in pens during six months. Values of SGR are regardless of the water reservoir and culture system superior to 0.62 \%day $^{-1}$ from Ouattara et al. (2003) who fed $S$. melanotheron with local feed containing $30 \%$ of crude protein and $0.97 \%$ day $^{-1}$ in Nile tilapia (Gibtan et al., 2008). They are also high compared to $0.85 \%$ day $^{-1}$ and 0. $74 \%$ day $^{-1}$ observed during a 140-day experimental rearing of monosex males (100 individuals. $\mathrm{m}^{-3}$ ) of $T$. zillii and T. guineensis, respectively (Nobah et al., 2008). But, $1.62 \%$ day $^{-1}$ observed as SGR by Nunoo and Asase (2017) in $O$. niloticus reared in cages for 82 days is quite high compared to our results at Batran. Overall, findings from the present study reinforced the knowledge that among all tilapia species, $O$. niloticus is the most suitable for fish farming because, despite the fact that we used mixed sex juveniles, all calculated growth parameters are good compared with the other rearing monosex male's species.

In aquaculture, fish growth potential and production are closely related to the efficiency with which they valorize distributed feed. For this, feed utilization assessment is important. It is known that a good feed utilization performance leads to a positive impact in reducing the fish production cost. Overall, 
feed utilization parameters values from our work are very interesting compared to the values obtained in tilapia S. melanotheron and T. guineensis reared with local manufacturing feed in floating cages and cageenclosures in Ivory Coast (Legendre, 1986; Ouattara, 2004; Nobah, 2007). Calculated FE-PER are higher than those noticed with Nile tilapia males, $0.26-0.88$ in cages and $0.28-0.92$ in pens by Chakraborty and Banerjee (2009). FE are greatly beyond the interval 0.33 to 1 mostly found in fish culture (Coche, 1982; Naylor et al., 2000). This recorded good performance could be linked to the quality of the distributed feed and the feeding method used that did not result in feed loss. "Le Gouessant" is a balanced and extruded fish feed, known for their high stability in water and better nutrients use in fish compared to a single pelleted diet (Glencross et al., 2008). In addition, the best nutrients utilization and fish growth in this study could also be influenced by the presence of periphytic community which significantly complement exogenous feed and contribute to the efficiency of their use by fish in in captivity (Azim, Verdegem, Mantingh, Van Dam, \& Beveridge, 2003; Bamba, Ouattara, Moreau, \& Gourene, 2007). For instance, in floating net-cages fixed in an earthen pond, Nile tilapia fed with the lower protein diets and periphyton performed better than those fed with control diet containing high level of protein (Eman, Shymaa, Elham, Abdel-Fattah, \& Asmaa, 2015). Irrespective of the rearing system and water reservoir, protein had a large part in the gross energy formation in fish. This is due to the fact that, based on our biochemical results, protein was a major component in fish as compared to lipid and carbohydrate. Fish produced in northern Benin water reservoirs will have a significant contribution to the improvement of nutritional status of consumers. We also noticed that protein had trend to be more in pens in which, fish had higher final body weight. Similar observations have been made by Abdelghany and Mohammed (2002) who reported that body protein content increases with wet weight in Nile tilapia. The present study revealed that lipid productive value and energy retention was significantly higher at Batran water reservoir. This indicates that lipid was a preferred energy reserve for deposition and further mobilization in $O$. niloticus living in stressed aquatic ecosystems. According to Froyland, Lie, and Berge (2000), the main function of lipid in fish is to generate energy in the form of ATP provided by the $\beta$ oxidation of fatty acids. However, it is important to remark that values of lipid in all fish were less than $5 \%$ of their fresh matter and confirmed that Nile tilapia produced in northern Benin water reservoirs remains a lean fish (Suriah, Huah, Hassan, \& Daud, 1995). Furthermore, it is well to notice that with both culture systems installed in northern Benin water reservoirs, the fish harvested, contain acceptable levels of pesticide residues and their consumption has no pesticides potential adverse effects on human health (Pèlèbè, 2019).

\section{Conclusion}

This study constitutes the first investigation on the potential of the numerous northern Benin water reservoirs for fish farming. From our findings, cages farming of $O$. niloticus is technically feasible in the water reservoirs located both in the cotton basin and outside in northern Benin. Fish growth is better in cage bottom layer set on the seaground with contact to sediment at Songhaï water reservoir situated outside the basin cotton and similarity exists between the two culture systems regardless of the water reservoir location. Considering zootechnical performance, nutritional quality obtained and ecotoxicological risks, only cage bottom layer suspended above seaground without contact to sediment can be recommended for 0 . niloticus culture inside the cotton basin whereas, both culture systems can be used for Nile tilapia rearing outside the cotton basin.

\section{Acknowledgements}

The present work was done as part of the first author's PhD thesis. We are grateful to the AquaToxBenin project for according us technical facilities. We also thank the International Foundation for Science (IFS Grant $N^{\circ}$ A_6207-1), the Cooperation and Cultural Action Service (SCAC, File 0185BENB170012) of the French Embassy in Benin and the Commission of the West African Economic and Monetary Union (UEMOA, Program of supporting training and research of excellence) for their financial support. PELEBE E.O. Rodrigue thanks the African-German Network of Excellence in Science (AGNES) for granting a Mobility Grant in 2019; this Grant is generously sponsored by German Federal Ministry of Education and Research and supported by the Alexander von Humboldt Foundation.

\section{References}

Abdelghany, A. E., \& Mohammed, H. A. (2002). Effects of feeding rates on growth and production of Nile tilapia, common carp and silver carp polycultured in fertilized ponds. Aquaculture Research, 33, 415-423. https://doi.org/10.1046/j.1365-2109.2002.00689.x

Adam, K.S., \& Boko, M. (1993). Le Bénin. EDICEF, 2ème édition : Paris, 93pp.

Adéchian, A.S., Baco, N.M., Akponikpe, I., Imorou Toko, I., Egah, J., \& Affoukou, K. (2015). Les pratiques paysannes de gestion des pesticides sur le maïs et le coton dans le bassin cotonnier du Bénin ". VertigO - la revue électronique en sciences de l'environnement, 15 (2). https://id.erudit.org/iderudit/1035837ar

Agbohessi, P.T., Imorou Toko, I., \& Kestemont, P. (2012). Etat des lieux de la contamination des écosystèmes aquatiques par les pesticides organochlorés dans le bassin cotonnier béninois. Cahiers Agricultures, $21: 46$ 56. https://doi.org/10.1684/agr.2012.0535

Agbohessi, T.P., Imorou Toko, I., Ouédraogo, A., Jauniaux, T., Mandiki, S.N.M., \& Kestemont, P. (2015). Assessment of the health status of wild fish inhabiting a cotton basin 
heavily impacted by pesticides in Benin (West Africa). Science of the Total Environment, 506-507, 567-584. https://doi.org/10.1016/j.scitotenv.2014.11.047

Agbohessi, T.P., ImorouToko, I., Yabi, A.J., DassoundoAssogba, J.F.C., \& Kestemont, P. (2011). Caractérisation des pesticides chimiques utilisés en production cotonnière et impact sur les indicateurs économiques dans la Commune de Banikoara au Nord du Bénin. International Journal of Biological and Chemical Sciences, 5(5), 1828-1841.

http://dx.doi.org/10.4314/ijbcs.v5i5.6

Aïzonou, R., Achoh, M. E., Agadjihouèdé, H. (2019). Analysis of practice of cage aquaculture system in Toho Todougba lagoon, Southern Benin (West Africa). Aquaculture Studies, 19(2), 113-123 http://doi.org/10.4194/26186381-v19_2_04

AOAC (Association of Official Analytical Chemists). (2003). Official methods of analysis, Metals and other elements USA, 1054-1089pp.

Azim, M.E., Verdegem, M.C.J., Mantingh, I., Van Dam, A.A., \& Beveridge, M.C.M. (2003). Ingestion and utilization of periphyton grown on artificial substrates by Nile tilapia Oreochromis niloticus L. Aquaculture Research, 34, 8592.

Azonsi, F., Tossa, A., Kpomasse, M., Lanhoussi, F., Zannou, A., \& Gohoungossou, A. (2008). Atlas hydrographique du Bénin : système de l'information sur l'hydrographie. Direction Générale de l'eau, Cotonou, Bénin, 22pp.

Balarin, J.D. \& Hatton, J. D. (1979). Tilapia: A guide to their biology and culture in Africa. Unit of Aquatic Pathobiology, Stirling University, 174pp.

Bamba, Y., Ouattara, A., Moreau, J., \& Gourene, G. (2007). Apports relatifs en nourritures naturelle et artificielle dans I'alimentation du tilapia Oreochromis niloticus en captivité. Bulletin français de la pêche et de la protection des milieux aquatiques, 386, 55-68.

Beveridge, M.C.M. (1985). Pisciculture en cage et enclos. Modèles de charge biotique et impact écologique. FAO Document Technique sur les Pêches $N^{\circ} 255,126 \mathrm{pp}$.

Chakraborty, B.S., \& Banerjee, S. (2009). Culture of monosex Nile Tilapia under different traditional and nontraditional methods in India. World Journal of Fish and Marine Sciences, 1 (3), 212-217.

Chakraborty, B.S., Mazumdar, D., Chatterji, U., \& Banerjee, S. (2011). Growth of mixed-sex and monosex Nile tilapia in different culture systems. Turkish Journal of Fisheries and Aquatic Sciences, 11, 131-138. http://dx.doi.org/10.4194/trjfas.2011.0117

Coche, A. G. (1982). Cage culture of tilapias. In Pullin, R. S. V, Lowe McConnell, R. H., The biology and culture of tilapias (p.205-246). Manila, Philippines : ICLARM

Colman, J., Lardinois, P., Rabelahatra, A., Rafaliarison, J., van den Berg, F., Heritiana, R., \& Janssen, J. (1992). Manuel pour le développement de la pisciculture à Madagascar. Document Technique $\mathrm{N}^{\circ} 4$. http://www.fao.org/3/AB847F/AB847F03.htm

El-Saidy, D.S.M.D., \& Gaber, A.M.M. (2005). Effect of dietary protein levels and feeding rates on growth performance, production traits and body composition of Nile tilapia, Oreochromis niloticus (L.) cultured in concrete tanks. Aquaculture Research, 36, 163-171. http://dx.doi.org/10.1111/j.1365-2109.2004.01201.x

Eman, M.S., Shymaa, M. S., Elham, A.W., Abdel-Fattah, M.E-S., \& Asmaa, I. A. (2015). Evaluation of Periphyton as a Food Source for Nile Tilapia (Oreochromis niloticus) Juveniles
Fed Reduced Protein Levels in Cages. Journal of Applied Aquaculture, 27 (1), 50-60. https://doi.org/10.1080/10454438.2014.967073

Froyland, L., Lie, O., \& Berge, R.K. (2000). Mitochondrial and peroxisomal beta oxidation capacities in various tissues from Atlantic salmon Salmo salar. Aquaculture Nutrition, 6, 85-89. https://doi.org/10.1046/j.13652095.2000.00130.x

Garcia, F., Romera, D.M., Gozi, K.S., Onaka, E.M., Fonseca, F.S., Schalch, S.H.C., ...Maria Portella, C. (2013). Stocking density of Nile tilapia in cages placed in a hydroelectric reservoir. Aquaculture, 410-411, 51-56. https://doi.org/10.1016/j.aquaculture.2013.06.010

Gibtan, A., Getahun, A., \& Mengistou, S. (2008). Effect of stocking density on the growth performance and yield of Nile tilapia [Oreochromis niloticus (L., 1758)] in a cage culture system in Lake Kuriftu, Ethiopia. Aquaculture Research, 39, 1450-1460. https://doi.org/10.1111/j.1365-2109.2008.02021.x

Glencross, B., Blyth, D., Tabrett, S., Bourne, N., Irvin, S., Anderson, M., Smullen, R. (2012). An assessment of cereal grains and other starch sources in diets for Barramundi (Lates calcarifer)-implications for nutritional and functional qualities of extruded feeds. Aquaculture Nutrition, 18, 388-399. https://doi.org/10.1111/j.13652095.2011.00903.x

Gouda, A-I. (2018). Analyse des risques environnementaux liés aux pratiques phytosanitaires dans les écosystèmes aquatiques du bassin cotonnier (Nord Bénin) (PhD thesis). University of Liège-Gembloux Agro-Bio Tech, Gembloux, Belgium.

Houndekon, A., (2014). Analyse comparative des systèmes de production $\mathrm{du}$ coton biologique et du coton conventionnel au Benin. Journal de la Recherche Scientifique de l'Université de Lomé, 16 (3).

Imorou Toko, I., Pèlèbè, E.O.R., Tonato, R., Guedegba, N.L., Agbohessi, T.P., \& Kestemont, P. (2018). Indices biométriques et paramètres de croissance du tilapia Oreochromis niloticus (Linnaeus, 1758) exposé aux pesticides agricoles dans les retenues d'eau du NordBénin. International Journal of Biological and Chemical Sciences, 12 (3), 1401-1414. http://dx.doi.org/10.4314/ijbcs.v12i3.26

INSAE (Institut National de la Statistique et de l'Analyse Economique). (2016). Statistiques du Commerce Extérieur - Bulletin Trimestriel- Quatrième Trimestre 2016. INSAE, Cotonou, 89pp.

Jobling, M. (1983). A short review and critic of methodology used in fish growth and nutrition studies. Journal of Fish Biology, 23, 685 -703. http://dx.doi.org/10.1111/j.10958649.1983.tb02946.x

Jobling, M. (1994). Fish Bioenergetics. London, United Kingdom: Chapman and Hall, 310pp.

Kestemont, P., Micha, J-C., \& Falter, U. (1989). Les méthodes de production d'alevins de Tilapia nilotica. Programme de mise en valeur et de coordination de l'Aquaculture. ADCP/REP/89/46. PNUD/FAO, Rome, Italy $132 \mathrm{p}$. http://www.fao.org/docrep/t8655f/t8655f00.htm

Kpenavoun, S.C., Gandonou, E., Adegbidi, A., \& Abokini, E. (2017). Mesure et déterminants de l'efficacité technique des pisciculteurs du Bénin. International Journal of Biological and Chemical Sciences, 11(5), 21942208. http://dx.doi.org/10.4314/ijbcs.v11i5.20 
Lawani, R.A.N., Kelome, N.C., Agassounon Djikpo Tchibozo, M., Hounkpe, J.B., \& Adjagodo, A. (2017). Effets des pratiques agricoles sur la pollution des eaux de surface en République du Bénin. Larhyss Journal, 30, 173-190.

Legendre, M. (1986). Influence de la densité, de l'élevage monosexe et de l'alimentation sur la croissance de Tilapia guineensis et de Sarotherodon melanotheron élevés en cage-enclos en lagune Ebrié (Côte d'Ivoire). Revue d'Hydrobiologie Tropicale, 19, 19-29.

Legendre, M., Hem, S., \& Cissé A., (1989). Suitability of brackish water tilapia species from the Ivory Coast for lagoon aquaculture. II - Growth and rearing methods. Aquatic Living Resources, 2, 81-89. http://dx.doi.org/10.1051/alr:1989010

MAEP (Ministère de l'Agriculture, de l'Elevage et de la Pêche). (2017). Plan Stratégique de Développement du Secteur Agricole (PSDS 2025) / Plan National d'Investissements Agricoles et de Sécurité Alimentaire et Nutritionnelle (PNIASAN) (2017-2021). Cotonou, 131pp.

Matthess, A., van den Akker, E., Chougourou, D., \& Midingoyi, S.J. (2005). Le coton au Bénin : Compétitivité et durabilité de cinq systèmes culturaux cotonniers dans le cadre de la filière. Eschborn, Germany: GTZ (Deutsche Gesellschaftfür Technische Zusammenarbeit), 206pp

Mélard, C. (1986). Les bases biologiques de l'élevage intensif du tilapia du Nil. Cahiers d'Ethologie appliquée, 3(6), 1224.

Morissens, P., Roche, P., \& Aglinglo, C. (1986). La pisciculture intensive en enclos dans les grandes lagunes du sud-est Bénin. Revue Bois et Forêts des Tropiques, 213(3), 51-70.

Naylor, R.L., Goldbur, G.R.J., Primevera, J.H., Kautskky, N., Beveridge, M.C.M., Clay, J., Folke, C., Lubchenco, J., Mooney, H., \& Troell, M. (2000). Effect of aquaculture on world fish supplies. Nature, 405, 1017-1024. http://dx.doi.org/10.1038/35016500

Nobah, C.S.K. (2007). Critères d'identification et performances zootechniques des tilapias hybrides [Tilapia zillii (Gervais, 1948) $\times T$. guineensis (Bleeker, 1862)] dans trois structures d'élevage: cages flottantes (Lac d'Ayamé), étangs en terre et bassins en béton (Aboisso) (PhD thesis). University of Cocody, Abidjan, Côte d'Ivoire.

Nobah, C.S.K., Kone, T., Ouattara, N.I., Kouamelan, E.P., N'douba, V., \& Snoeks, J. (2008). Etude des performances de croissance de deux tilapias (Tilapia zillii et $T$. guineensis) et de leurs hybrides en cage flottante. Cybium, 32(2), 131-136.

Nunoo, E.K.F., \& Asase, A. (2017). Comparative growth performance of Oreochromis niloticus (Linnaeus, 1758) in cages at different stocking densities. International Journal of Fisheries and Aquatic Studies, 5(4), 279-283.

Ouattara, N.I., Teugels, G.G., N'Douba, V., \& Philippart, J-C. (2003). Sarotherodon melanotheron (Cichlidae). Comparative study of the effect of stocking density on growth performance of landlocked and natural populations under cage culture conditions in Lake Ayamé (Côte d'Ivoire). Aquaculture Research, 34, 12231229.

Ouattara, N.I. (2004). Etude du potentiel aquacole d'une population du tilapia estuarien Sarotherodon melanotheron Rüppell (1852) isolée dans le lac de barrage d'Ayamé (Côte d'Ivoire) (PhD thesis). University of Liège, Liège, Belgium.

Pèlèbè, E.O.R. (2019). Performances d'élevage et qualité sanitaire des poissons Oreochromis niloticus (Linnaeus, 1758 ) et Clarias gariepinus (Burchell, 1822) produits dans les retenues d'eau du nord du Bénin (Afrique de l'Ouest) (PhD thesis in Cotutorship). University of Parakou and Félix HOUPHOUET-BOIGNY University, Parakou and Abidjan, Benin and Côte d'Ivoire.

Pèlèbè, E.O.R., Imorou Toko, I., Ouattara, N.I., Attakpa, E.Y. \& Montchowui, E.H. (2019). Potentialities and constraints of fish farming in the northern Benin water reservoirs: what are the challenges? International Journal of Fisheries and Aquatic Studies, 7(5), 98-105.

Ross, L.G. (2000). Environmental physiology and energetics. In M.C.M. Beveridge \& B.J. McAndrew (Eds), Tilapias: Biology and Exploitation (pp. 89-128). Great Britain: Kluwer Academic Publishers.

Rurangwa, E., van den Berg, J., Lalèyè, A.P., van Duijn, A.P., \& Rothuis, A. (2014). Mission exploratoire Pêche, Pisciculture et Aquaculture au Bénin. Un quick scan du secteur pour des possibilités d'interventions. IMARES report C072/14 LEI report 14-049 (IMARES - Institute for Marine Resources \& Ecosystem Studies), 70p.

Schreck, C.B., \& Moyle, P.B. (1990). Methods for fish biology. American Fisheries Society, Bethesda, Maryland, 704pp.

Suriah, A-R., Huah, T.S., Hassan, O., \& Daud N.M. (1995). Fatty acid composition of some Malaysian freshwater fish. Journal of Food Chemistry, 54, 45-49. http://dx.doi.org/10.1016/0308-8146(95)92660-C

Ton, P. (2004). La production du coton au Bénin, Projet d'analyse d'une spéculation agricole par pays, financé par le programme "Renforcement des capacités commerciales" de la FIPA (Fédération Internationale des Producteurs Agricoles), Cotonou et Amsterdam, FUPRO BENIN N ${ }^{\circ}$ 15.4.04. 279K, 52pp.

Vigano, L., Arillo, A., Falugi, C., Melodia, F., \& Polesello, S. (2001). Biomarkers of exposure and effect in flounder (Platichthys flesus) exposed to sediments of the Adriatic Marine Pollution Bulletin, 42, 887-894. http://dx.doi.org/10.1016/S0025-326X(01)00047-9

Wabi, K., Gbaguidi, M., Anihouvi, V.B., Azokpota, P., \& Kpodékon, M. (2012). Evaluation de la pollution microbienne et chimique de Trachurus trachurus, Scomber scombrus et Sardinella aurita, trois espèces de poissons importées et consommées au Bénin. 3ème forum du projet GVal-Sécurité alimentaire (Renforcer les capacités de Gestion et de Valorisation de la recherche dans le domaine de la Sécurité Alimentaire en Afrique de l'Ouest), 15pp.

Zoumenou, M.Y.G.B., Aïna, M.P., Imorou Toko, I., Igout, I., Douny, C., Brose, F., ... Scippo, M-L. (2019). Occurrence of Acetamiprid Residues in Water Reservoirs in the Cotton Basin of Northern Benin. Bulletin of Environmental Contamination and Toxicology, 102, 7-12. http://dx.doi.org/10.1007/s00128-018-2476-4

Zoumenou, Y.M.B.G. (2019). Etude de la contamination de l'environnement et des produits de pêche par les pesticides, dans le bassin cotonnier béninois ( $\mathrm{PhD}$ thesis). University of Liège, Liège, Belgium. 